2015-08-13

\title{
A critical comparison on biocompatibility of different phases of sol-gel derived calcium phosphates as bone graft materials
}

\author{
Natesan, K
}

http://hdl.handle.net/10026.1/3519

\subsection{6/jbt.2015.1364}

Journal of Biomaterials and Tissue Engineering

American Scientific Publishers

All content in PEARL is protected by copyright law. Author manuscripts are made available in accordance with publisher policies. Please cite only the published version using the details provided on the item record or document. In the absence of an open licence (e.g. Creative Commons), permissions for further reuse of content should be sought from the publisher or author. 


\title{
A critical comparison on biocompatibility of different phases of sol-gel derived calcium phosphates as bone graft materials
}

\author{
K. Natesan ${ }^{1}$, W. Shah ${ }^{2}$, H. R. Le ${ }^{3 *}$, C. Tredwin ${ }^{1}$ \\ ${ }^{1}$ Peninsular Schools of Medicine and Dentistry, Plymouth University, Plymouth, United Kingdom \\ ${ }^{2}$ School of Biology and Health Sciences, Plymouth University, Plymouth, United Kingdom \\ ${ }^{3}$ School of Marine Science and Engineering, Plymouth University, Plymouth, United Kingdom \\ Correspondence Author (H. R. Le): huirong.le@plymouth.ac.uk
}

\begin{abstract}
Calcium Phosphate cement has been the subject of intense investigation over the past few years. This study compares difference in biocompatibility between the three main phases of Ca-P, namely Hydroxyapatite, Dicalcium phosphate and $\beta$-Tricalcium phosphate. It involves composite preparation followed by cell test. Material parameters were stoichiometry (Hydroxyapatite with Ca-P ratio of 1.67, Dicalcium phosphate with Ca-P ratio of 1.0, $\beta$-Tricalcium phosphate with $\mathrm{Ca}-\mathrm{P}$ ratio of 1.50) and crystallographic structure and arrangement. The Composites in concern were produced by mixing PVA (polyvinyl alcohol) and Ca-P in equal fraction. Cell test was performed for $24 \mathrm{~h}$ and 7 days.

Biocompatibility analysis was performed both qualitatively and quantitatively. XRD, FTIR, SEM and TEM were used to analyse materials at various stages of the research. All calcium phosphate composites were biocompatible with cells. Hydroxyapatite ceramic expressed highest biocompatibility followed by Dicalcium phosphate and $\beta$-Tricalcium phosphate after $24 \mathrm{~h}$ cell test, whereas, after the 7-days test biocompatibility of Dicalcium phosphate was comparable to Hydroxyapatite. This study shows that Dicalcium phosphate is a better alternative to Hydroxyapatite, where biodegradation is crucial for patients' recovery.
\end{abstract}

Keywords: Hydroxyapatite, Dicalcium Phosphate, $\beta$-Tricalcium Phosphate, biocompatibility, sol-gel 


\section{Introduction}

Muscoskeletal disorder is the highest cause of morbidity and disability globally. Over the decades a variety of materials have been researched to fill bone defects. Ideally, synthetic materials should be, biocompatible ${ }^{1}$, show minimal fibrotic reaction ${ }^{2}$, remodel, support new bone formation $^{3}$ and possess mechanical properties as high or better than those of cortical bones to be used as bone grafts ${ }^{1,4}$. Synthetic materials may consist of metals, ceramics, polymers and composites ${ }^{5,6}$. The broad range of materials can be explained by the fact that none of these materials unite the five essential criteria mentioned above.

Ceramics such as calcium phosphates (Ca-P), calcium sulphates and Bioglass ${ }^{\circledR}$ are of interest as bone implants since they closely resemble natural bone structure ${ }^{7,8}$. These ceramics are used individually or combined to mimic natural bones ${ }^{9-12}$. It has been reported that various CaP such as Hydroxyapatite $(\mathrm{HA})^{13}, \alpha$ and $\beta$-Tricalcium phosphates $(\alpha, \beta-\mathrm{TCP})^{10}$, octacalcium phosphates, tetra calcium phosphates ${ }^{14}$ and anhydrous Dicalcium phosphates (DCP) ${ }^{15,16}$ are especially suitable as biomaterials as they closely resemble the inorganic phase of natural bones. However, different phases of Ca-P have varying effect on the growth of cells ${ }^{17}$. Therefore, it is vital to understand the influence of synthetic Ca-P on osteointegration.

Natural bone is made up of non-stoichiometric $\mathrm{HA}\left(\mathrm{Ca}_{10-\mathrm{x}}\left(\mathrm{HPO}_{4}\right)_{6-\mathrm{x}}(\mathrm{OH})_{2-\mathrm{x}}\right)$ which contains other ions. For long, synthetic HA and $\beta$-TCP have been discerned as some of the most important bone substitute materials ${ }^{18,19}$. While HA is seemingly an active bio-ceramic with the capacity to bond firmly to bone, it is not capable of dissolving in a physiological environment ${ }^{20}$. This blocks the formation of new bone, hindering the remodification process, resulting in poor local stability ${ }^{10}$. Similarly, the degradation of $\beta$-TCP has been reported as undeterminable as it dissolves 12.3 times faster than HA in acidic medium and 22.3 times faster in basic medium ${ }^{21}$. They differ not only in their composition and physical properties from each other and from 
Accepted by Journal of Biomaterials and Tissue Engineering, 31 July 2015

bone, but also in their rate of absorption ${ }^{12,22}$. The scientific community is still looking for adequate bone graft substitutes despite 40 years of research.

One of the main controlled biodegradable osteoconductive material is DCP. DCP is soluble and gradually dissolves at the implant site, releasing calcium and phosphate ions into the biological medium, allowing new bone formation ${ }^{21}$.

Bone scaffolds are required to provide biocompatibility and strength; however, inorganic materials fail to provide strength on their own. In order to overcome the mechanical weakness of inorganic material, a polymeric constituent is usually introduced to enrich strength of final materials $^{23}$. Polyvinyl Alcohol (PVA) is a hydrophilic, synthetic semi-crystalline polymer, which is biocompatible, non-carcinogenic and one of the most commonly used polymers in biomedical applications ${ }^{24-28}$. Physical interaction of PVA with the surface of inorganic materials is possible without the incorporation of any chemical additives, as PVA has high concentration of hydroxyl pendent groups which can easily crosslink with the surface of the material's hydroxyl group ${ }^{23}$. Although PVA is highly biocompatible, fewer researchers have paid close attention to the critical behaviour of cells in the presence of PVA while comparing the three main phases (HA, DCP, $\beta$-TCP) of Ca-P composites. Hence, it is critical to compare cell growth and response to the above mentioned composites and evaluate the science behind this difference.

This paper discusses a bioactive concept on an optimum balance between three phases of Ca-P. The topics include: description of these materials in terms of their physicochemical and crystallographic properties; characterization of interface; effect of individual components on cell growth and why DCP is a better alternative than HA and $\beta$-TCP. 
Accepted by Journal of Biomaterials and Tissue Engineering, 31 July 2015

\section{Materials and Methods}

\subsection{Materials}

Calcium Acetate $\mathrm{Ca}\left(\mathrm{CH}_{3} \mathrm{COO}\right)_{2}(\mathrm{C} 1000$, Sigma, UK) and Ammonium Phosphate $\left(\mathrm{NH}_{4}\right)_{2} \mathrm{HPO}_{4}(215996$, Sigma, UK) were used as starting materials to prepare the three phases of Ca-P. PVA ( Mw -70,000-100,000, Sigma, UK) was used as the binder. Sodium Hydroxide (NaOH) (S8045, Sigma, UK) was used to maintain pH. Distilled water was used throughout the experiments.

\subsection{Sol-Gel Precipitation Process}

\section{Hydroxyapatite Preparation}

HA particles were synthesized by the wet sol-gel precipitation method. The synthesis process involved simultaneous addition of $0.1 \mathrm{M} \mathrm{Ca}\left(\mathrm{CH}_{3} \mathrm{COO}\right)_{2}$ solution and $0.06 \mathrm{M}\left(\mathrm{NH}_{4}\right)_{2} \mathrm{HPO}_{4}$ solution in the reaction vessel. $\mathrm{Ca} / \mathrm{P}$ ratio was maintained at 1.67 . The solution was stirred at a constant rate of $400 \mathrm{rpm}$ using magnetic stirrer while temperature was maintained at $40^{\circ} \mathrm{C}$ during reaction and aging. $\mathrm{NaOH}$ was added to maintain $\mathrm{pH}$ at $9.5-10$. The solution was stirred vigorously for $1 \mathrm{~h}$ and was allowed to age for $24 \mathrm{~h}$. The obtained white precipitate was filtered, dried in vacuum at $90^{\circ} \mathrm{C}$ for $24 \mathrm{~h}$ and crushed using mortar and pestle and stored at room temperature.

\section{Dicalcium Phosphate Preparation}

DCP was prepared by the addition of $0.1 \mathrm{M} \mathrm{Ca}\left(\mathrm{CH}_{3} \mathrm{COO}\right)_{2}$ and $0.1 \mathrm{M}\left(\mathrm{NH}_{4}\right)_{2} \mathrm{HPO}_{4}$ in reaction vessel. The solution was stirred at a constant rate of $400 \mathrm{rpm}$ using magnetic stirrer while $\mathrm{pH}$ was maintained at 7 during reaction and aging time. The solution was stirred for $1 \mathrm{~h}$ and left to age for $24 \mathrm{~h}$. Thereafter, the solution was filtered and the precipitate was dried at $60{ }^{\circ} \mathrm{C}$ for $2 \mathrm{~h}, 100^{\circ} \mathrm{C}$ for $24 \mathrm{~h}$ and $300^{\circ} \mathrm{C}$ for $2 \mathrm{~h}$. The powder was then crushed to obtain uniform particle size using mortar and pestle and stored at room temperature. 
Accepted by Journal of Biomaterials and Tissue Engineering, 31 July 2015

\section{B-Tricalcium Phosphate preparation}

$\beta$-TCP was prepared according to Stoia et al ${ }^{20}$. In brief, $0.3 \mathrm{M} \mathrm{Ca}\left(\mathrm{CH}_{3} \mathrm{COO}\right)_{2}$ and

$0.2 \mathrm{M}\left(\mathrm{NH}_{4}\right)_{2} \mathrm{HPO}_{4}$ were added to the reaction vessel simultaneously. This precipitated nonstoichiometric HA which was stirred continuously using magnetic stirrer at the rate of 400 rpm. $\mathrm{pH}$ was maintained between 9.5 - 10 using $\mathrm{NaOH}$ throughout precipitation and aging. The precipitate was left to age for $24 \mathrm{~h}$ and was filtered out and dried at $60{ }^{\circ} \mathrm{C}$ for $2 \mathrm{~h}$ and at $105^{\circ} \mathrm{C}$ for $24 \mathrm{~h}$. The dried powder was annealed at $1000^{\circ} \mathrm{C}$ for $8 \mathrm{~h}$ and crushed using mortar and pestle and stored at room temperature.

\subsection{Composite Preparation}

To prepare the composites, $20 \%$ PVA solution was produced. This was stable for a few weeks and was stored for later use.

The composites were made by mixing Ca-P with 20\%PVA solution. Different ratio combinations were tried to attain workability of the material and 1:1 ratio by weight was used for all sample preparations. The composites were hand mixed using spatula and were placed in aluminium moulds with the dimensions of $15 \mathrm{~mm}(\mathrm{D}) \times 5 \mathrm{~mm}(\mathrm{H})$. For each material, a number of test samples were produced. Pressure was applied individually to each sample with a mechanical hand press for 5 minutes which was equivalent to $26 \mathrm{MPa}$. The mould with the samples was then placed at $40^{\circ} \mathrm{C}$ for $24 \mathrm{~h}$ to dry. After $24 \mathrm{~h}$ the samples were removed from the mould and stored at room temperature.

\subsection{Sample Characterisation}

\section{Electron Microscopy}

To investigate morphology and particle size of the powders, Transmission Electron Microscopy (TEM) analysis was performed using high resolution Transmission electron 
Accepted by Journal of Biomaterials and Tissue Engineering, 31 July 2015

microscope JEOL 1400 ( JEOL ltd, Japan). Small quantities of the precipitates were placed on the copper grid and were analysed at an accelerating voltage of $120 \mathrm{kV}$.

Scanning Electron Microscopy (SEM) analysis was performed on $24 \mathrm{~h}$ cell test specimens and 7 day specimens. All the specimens were fixed and dehydrated using freeze drying in liquid nitrogen and placed in the EMITECH K750 freeze drier for $24 \mathrm{~h}$. The samples were then mounted on conducting carbon stub and gold coated by EMITECH K550. SEM examinations were performed using $15 \mathrm{kV}$ accelerating voltage in a JEOL JSM -5600LV scanning electron microscope (JEOL ltd, Japan). All the samples were investigated at various magnifications.

\subsection{XRD Analysis}

Phase analysis of the Ca-P powders was conducted using X-ray diffraction (XRD). A Phillips X-ray diffractometer using $\mathrm{CuK} \alpha(\lambda=1.5418 \AA \AA)$ radiation with $\mathrm{X}$ celerator detector was employed. The diffractometer was operated at $45 \mathrm{kV}$ and $40 \mathrm{~mA}$ at a $2 \Theta$ range of $10-80^{\circ}$ using a step size of $0.03^{\circ}$ and a $50 \mathrm{~s}$ exposure.

\subsection{FTIR Analysis}

Fourier Transform Infrared spectroscopy (FTIR) analysis was performed to determine the functional groups in the phosphates and carbonate substitutes in the powders. All the samples were ground in a mortar and pestle and analysis was performed using spectra recorded by Bruker alpha P FTIR spectrometer utilizing diamond ATR. Each spectrum was the result of 16 accumulated scans at $4 \mathrm{~cm}^{-1}$ resolution. 


\section{Biocompatibility Test}

\subsection{Specimen Preparation for Cell Test}

Before performing the cell tests, specimens were sterilized in a controlled environment. Detailed procedure is described elsewhere ${ }^{29}$. In brief, samples were placed in $99 \%$ absolute ethanol for 30 minutes and placed in sterile petri dishes before drying at $80^{\circ} \mathrm{C}$ for $2 \mathrm{~h}$.

\subsection{Cell Culture}

Chinese Hamster Ovary (CHO) cells (supplied by the biomedical school, Plymouth University) were chosen because of their low cost and their quick response to implant materials. They were cultured in Ham's F-12 medium supplemented with 2mM L-Glutamine and $10 \%$ fetal bovine serum in $100 \%$ relative humidified atmosphere at $37^{\circ} \mathrm{C}$. Stock cultures of $\mathrm{CHO}$ cells were seeded in $25-\mathrm{cm}^{2}$ cell culture flasks at $1-2 \times 10^{6}$ cells $/ \mathrm{ml}$ of medium. Sub culture was carried out every 3 to 4 days.

\subsection{Cell Survival Studies}

Biocompatibility of the three materials was compared by performing $24 \mathrm{~h}$ cell test followed by 7 day cell test. Test was performed in triplicate. A static seeding method was used with $500 \mu \mathrm{l}$ media. $24 \mathrm{~h}$ cell test was performed by seeding samples at $7.2 \times 10^{5} \mathrm{cells} / \mathrm{ml}$, and then placed in a $37^{\circ} \mathrm{C}$ incubator for $24 \mathrm{~h}$ at $100 \%$ relative humidity. For the seven day cell test, same procedure was followed as mentioned above while nutrients were replenished every 48 h.

\subsection{Quantitative Analysis}

A new protocol was conceived for the quantitative analysis of the samples. Each sample was analysed at 4 different areas and the average was used to compare cell viability. Quantitative analysis was performed by generating a random number and alphabet. A grid was drawn and the generated coordinates were employed as the area of interest to study the cell growth and 
Accepted by Journal of Biomaterials and Tissue Engineering, 31 July 2015

density for each sample (Figure 1). Any coordinates directly neighbouring a previously chosen one was ignored. All the samples were analysed at the chosen co-ordinates and SEM images were taken at various magnifications $(70 x, 800 x, 1000 x, 2000 x)$. This protocol was followed to avoid human bias towards samples with higher or lower cell count. Images taken at 800x magnification were utilized for the analysis. Cell coverage was calculated based on looking at the coordinates and ascertaining if there was biological material on them.

Another grid with 100 coordinates was created and 20 coordinates were chosen in random. 800x magnification images were used for this purpose. This was performed on all the four coordinates that were randomly selected previously. The results were then averaged to differentiate the cell growth between the different samples.

\section{Results and Discussion}

\subsection{Microstructure of the Powders}

\section{Physical Properties}

The importance on microstructure of $\mathrm{Ca}-\mathrm{P}$ has been confirmed through the reports of many credible researchers ${ }^{15,16,18}$. This has led to the determination of the biocompatibility of various phases of Ca-P. Figure 2 compares the shapes and sizes of the crystals and composites. From the SEM observations of different composites, it is clearly noticed that crystal structure and arrangement vary significantly between three phases. HA crystals appear to be botryoidal or globular however, TEM observation of the powder reveals that they are short nano-rod like crystals with a size range between 90-200nm (Figure2a,b). DCP composite appears to be rectangular in SEM analysis as they are elongated, wide and flat than equant while TEM analysis of the powder shows that they are similar in shape to HA crystals but their size ranges between 193- $454 \mathrm{~nm}$ (figure 2c,d). $\beta$-TCP crystals appear to be globular with irregular shape in both TEM and SEM analysis (Figure 2e,f) . Their size is in 
micrometre scale which ranges between $0.70 \mu \mathrm{m}-3.74 \mu \mathrm{m}$. This immense difference in the size of crystals is due to the difference in annealing temperature of the three powders.

\subsection{XRD Analysis}

Microstructure of the powders were analysed to obtain their mineral composition. XRD patterns of synthesized powders are presented in figure 3. HA and DCP exhibit broad diffraction peaks indicating low crystallinity. Okazaki et al have stated that XRD patterns become sharper by increasing temperature which means that the crystallinity degree increases with temperature. This is observed in $\beta$-TCP powder where the peaks are sharp and narrow. The apatite phase forms peaks at $2 \Theta$ of $25.92^{\circ}, 31.8^{\circ}, 32.20^{\circ}, 32.93^{\circ}$. This pattern reveals that HA was either poorly crystalline or, more likely nanocrystalline as evidenced by the broad peaks. This pattern stands valid, as the results from the spectrum can be correlated with the TEM images which bear witness.

$\mathrm{HA}$ is one of the initial components in all the three powders. Annealing DCP at $300{ }^{\circ} \mathrm{C}$ has also produced broad spectrum peaks. The sharp peaks in $\beta$-TCP are due to the coarsening of grains during sintering process.

\subsection{FTIR Measurements}

FTIR analysis was carried out to elucidate the presence of PVA in the blended nanocomposites and to analyse any complex structural changes that might have occurred due to blending. The interaction (hydrogen bonding) between PVA, HA, DCP and TCP in the final composites were also analysed. The representative FTIR absorption spectra of pure (HA, DCP, $\beta$-TCP) powders ,PVA and composites (PVA - HA, PVA - DCP, PVA - $\beta$ TCP)is shown in figure 4 and summarized in Table 1.

The results indicate that incorporation of PVA into powders causes the formation of predominant broad absorption band associated with OH stretching of PVA from 3278-3296 $\mathrm{cm}^{-1}$ in all the composites. This result suggests the presence of strong hydrogen bonding in 
the composites. In addition, the major absorption bands of $\mathrm{PO}_{4}{ }^{3-}$ stretching which appears within the rage of $1100 \mathrm{~cm}^{-1}$ to $500 \mathrm{~cm}^{-1}$ on all the powders have a shift which can be attributed to the interaction between the molecules of PVA and the Ca-P powders.

Furthermore, the overall PVA crystallinity has decreased in composites which were clearly evidenced by the weakening of the crystalline band at $1138 \mathrm{~cm}^{-1}$.

FTIR spectrum of HA powder and composite shows the presence of most characteristic chemical groups $\mathrm{OH}^{-}, \mathrm{PO}_{4}{ }^{3-}, \mathrm{CO}_{3}{ }^{2-}$ as well as $\mathrm{HPO}_{4}{ }^{2-}$ groups that characterize nonstoichiometric HA. $\mathrm{PO}_{4}{ }^{3-}$ group forms intensive peak at 560 and $600 \mathrm{~cm}^{-1}$ and at $1000-1100$ $\mathrm{cm}^{-1}$. Absorbed water band is relatively wide, from 3500 to $2700 \mathrm{~cm}^{-1}$ (figure $4 \mathrm{a}, \mathrm{b}$ ). $\mathrm{CO}_{3}{ }^{2-}$ group forms weak peak at $875 \mathrm{~cm}^{-1}$ in the composite. Note that the band shape, width and intensity differ between the powder and Composite (figure 4a,c). Additional peaks can be seen at $1086 \mathrm{~cm}^{-1}$ in the HA composite spectrum which could be due to the interaction with PVA. These spectra also demonstrate low crystallinity degree as they were not thermally treated. Transmittance peaks can be observed (at 1568, 1455, $1420 \mathrm{~cm}^{-1}$ ) in the HA powder spectrum and (at $1418 \mathrm{~cm}^{-1)}$ in the HA composite spectrum for the presence of $\mathrm{CO}_{3}{ }^{2-}$. There is a decrease in the number of peaks and intensity in the final composite which confirms that there are fewer impurities.

It is of interest to note that transmittance peak associated with $\mathrm{P}_{2} \mathrm{O}_{7}$ molecules distinctly appeared at $719 \mathrm{~cm}^{-1}$ and $727 \mathrm{~cm}^{-1}$ in the spectrum of DCP and $\beta$-TCP powders. Presence of DCP is confirmed by the P-O stretching modes between $900-1200 \mathrm{~cm}^{-1}$ and hydrogen bonded $\mathrm{HPO}_{4}{ }^{2-}$ ions are observed at $1387 \mathrm{~cm}-1$.

In the FTIR spectra of $\beta$-TCP, $\mathrm{PO}_{4}{ }^{3-}$ groups are observed which is characteristic to $\beta$-TCP. In addition, the presence of $\mathrm{P}_{2} \mathrm{O}_{7}$ group can be observed in both the powder and composite, which is characteristic to calcium pyrophosphate phase. 
Accepted by Journal of Biomaterials and Tissue Engineering, 31 July 2015

\subsection{Biocompatibility Test}

When implanted in bone, Ca-P ceramics should provide cell anchorage sites and structural guidance to form new bone. To disclose the material's functionality behind the camouflage of osteoinduction few types of Ca-P ceramics were tested with fibroblast cells. Cell tests were conducted for $24 \mathrm{~h}$ and 7 days and at the end of the test period Ca-P composites with the cells were removed from the medium, freeze dried and observed in SEM for the presence of cells.

Many fibroblasts were easily visible on all the specimens (figure 5). The cells were large (12$14 \mu \mathrm{m})$ and showed well-defined margins and were clearly visible and easily distinguishable. However, their appearance differed on each material. SEM observation of the $24 \mathrm{~h}$ samples indicated presence of monolayer of cells. Cells on HA sample showed better cell growth followed by DCP and $\beta$-TCP. It can be seen from figure 5a that cells on HA samples are flat and expanding to make contact with nearby cells and had infiltrated through pores. Cells in DCP sample showed significant difference in morphology compared to HA counterpart. After $24 \mathrm{~h}$ test, cells appeared to be circular with extending cellular material but were not flat like cells grown on HA samples (figure $5 b$ ). Of all the materials studied, $\beta$-TCP exhibited least compatibility (Figures 5c). Subsequently, from figure 5d, it can be seen that 7 day samples showed presence of multilayer of cells. The cells were all interconnected and had created a coating on the sample. This also evidenced that PVA was bioactive.

Whilst it is known that the size and shape of particles contribute to the bioactivity of the material, the chemical composition also plays a vital role ${ }^{30}$. The presence of an additional $\mathrm{OH}$ group in HA is said to promote cell growth. However, after the 7 day test it can be seen from figure 5e that the growth of the cells in DCP sample are comparable to HA and they also have multilayer of cells. Hence it can be considered that over a period of time biocompatibility of the material is exhibited clearly and is comparable to HA. 
In $\beta$-TCP sample the growth of cells is still limited (figure 5f). This could be due to the lack of $\mathrm{OH}$ ions in the material. Size of the cells was relatively small compared to cells in the other two materials. Furthermore, a trend has been observed that better biocompatibility is exhibited in HA which is made of small particles followed by DCP and $\beta$-TCP. Another contributing factor could be the nonexistence of pores. It is well known that cells thrive in materials with a maximum pore size of $100 \mu \mathrm{m}$. Both HA and DCP materials exhibited pores in the range of 50-60 $\mu \mathrm{m}$ however, no pores were visible in $\beta$-TCP composite.

Quantitative analysis (figure 6) of the samples after $24 \mathrm{~h}$ and 7 day also revealed that HA had highest growth of cells while $\beta$-TCP had the least. Results were significant at $\mathrm{p}=0.05$ level at both tests. 1 day t-test yielded $t$ values of 9.95 for $\beta$-TCP and 3.05 for DCP. The t test results for 7 day cell study was $\mathrm{t}=14.2$ for $\beta$-TCP and $\mathrm{t}-4.07$ for DCP. The coverage and uniform spread of cells on the surface are important as the cellular distribution across the entire scaffold has great effect on overall sustainability. Therefore area coverage has been used to measure the biocompatibility of the materials. However, it can be observed in 7 day cell test that multilayer of cells have developed unlike $24 \mathrm{~h}$ sample where only monolayer of cells is observed.

Quantitative analysis confirmed that $\beta$-TCP had the lowest growth of fibroblast cells indicating low bioactivity. This was confirmed on both cell tests where $\beta$-TCP samples had low presence of cellular material compared to HA.

\section{Conclusion}

Ca-P synthesis methods and their technological parameters can significantly impact stoichiometry of the product, its grade of crystallization, particle size, bio-ceramic phase composition, thermal stability, microstructure and mechanical properties. The important technological parameters that impact properties of $\mathrm{Ca}-\mathrm{P}$ synthesis product and also of bio- 
ceramic are temperature of synthesis, $\mathrm{pH}$ of synthesis environment, reagent type and concentration as well as selection of raw materials and their purity and quality. All of the above mentioned also brings a significant impact on tissue response of these bio- ceramic implants.

The study was performed to observe the outcome of cell response on various phases of Ca-P. DCP was produced to evaluate its osteoinduction properties against HA and $\beta$-TCP. PVA was used to make the composites owing to its bioactive properties. All the specimens were tested with $\mathrm{CHO}$ cells for $24 \mathrm{~h}$ and 7 days to identify growth pattern and cell response. It is found that, HA showed better biocompatibility however, its inability to be reabsorbed to give way for the development of new bone is considered a disadvantage. Similarly, $\beta$-TCP did not exhibit biocompatibility to the standard of HA but its ability to resorb is highly appreciable. DCP showed improved cell adhesion over the period of 7 days and was comparable to that of HA. Hence, the findings conclude that DCP would be an ideal bone graft material as it is resorbable and cell study has shown significant improvement after the 7 day study.

\section{Acknowledgements}

The Authors would like to thank Dr. Roy Mote for his help with the microscopes. The authors would like to thank Dr. Simon Thompson from Nottingham Trent University for his help with XRD analysis. The authors would also like to thank Technician Lynne Cooper for her help in the cell lab. The authors would like to thank the peninsula school of medicine and Dentistry for providing financial support.

\section{Conflict Of Interest}

The authors certify that there is no conflict of interest regarding the material discussed in the manuscript 
Accepted by Journal of Biomaterials and Tissue Engineering, 31 July 2015

\begin{tabular}{|c|l|l|l|l|l|}
\hline & 1 & 2 & 3 & 4 & 5 \\
\hline $\mathrm{A}$ & & & & & \\
\hline $\mathrm{B}$ & & & & & \\
\hline $\mathrm{C}$ & & & & & \\
\hline $\mathrm{D}$ & & & & & \\
\hline $\mathrm{E}$ & & & & & \\
\hline
\end{tabular}

Figure 1. Model depicting the area of interest for quantitative analysis. The squares marked in red represent the area that was used for quantitative analysis using the SEM image. 

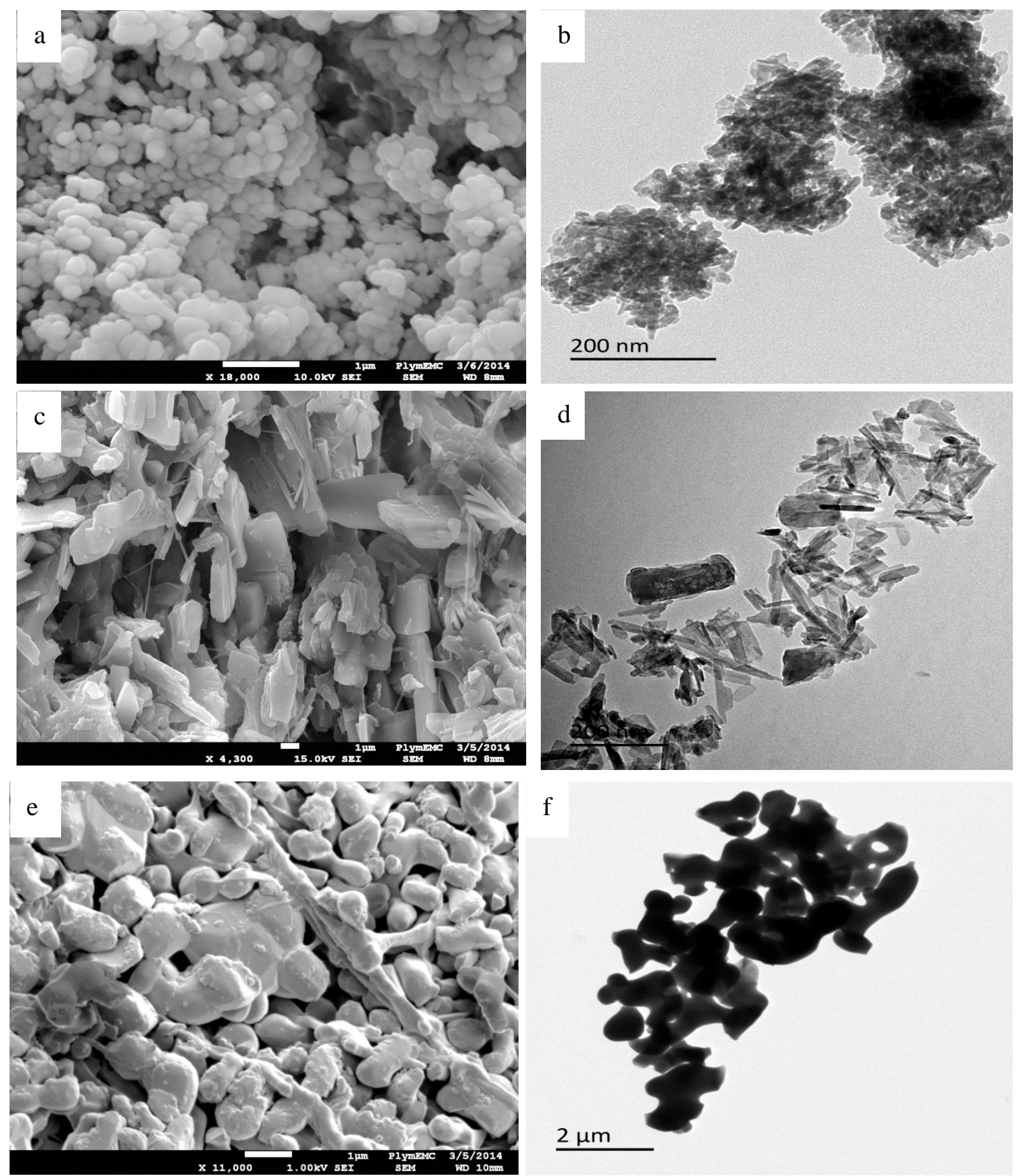

Figure 2. Microstructure analysis of Ca-P Powers and composites. a) SEM analysis of HA composite. b)TEM analysis of HA powders. c) SEM analysis of DCP. d)TEM analysis of DCP. e) SEM analysis of $\beta$-TCP powder. f) TEM analysis of $\beta$-TCP composite. 
Accepted by Journal of Biomaterials and Tissue Engineering, 31 July 2015

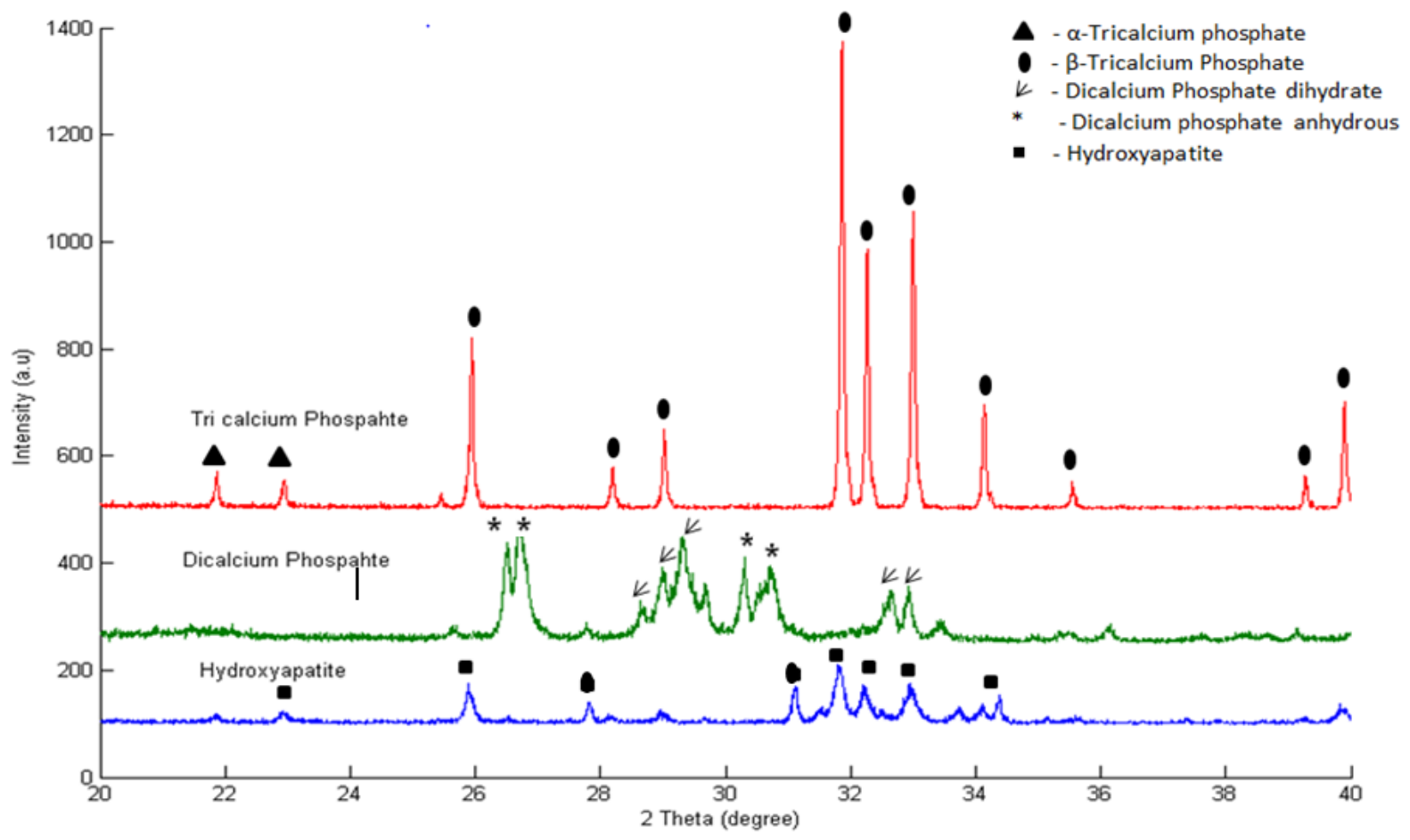

Figure 3. XRD analysis of HA, DCP, $\beta$-TCP 
Accepted by Journal of Biomaterials and Tissue Engineering, 31 July 2015
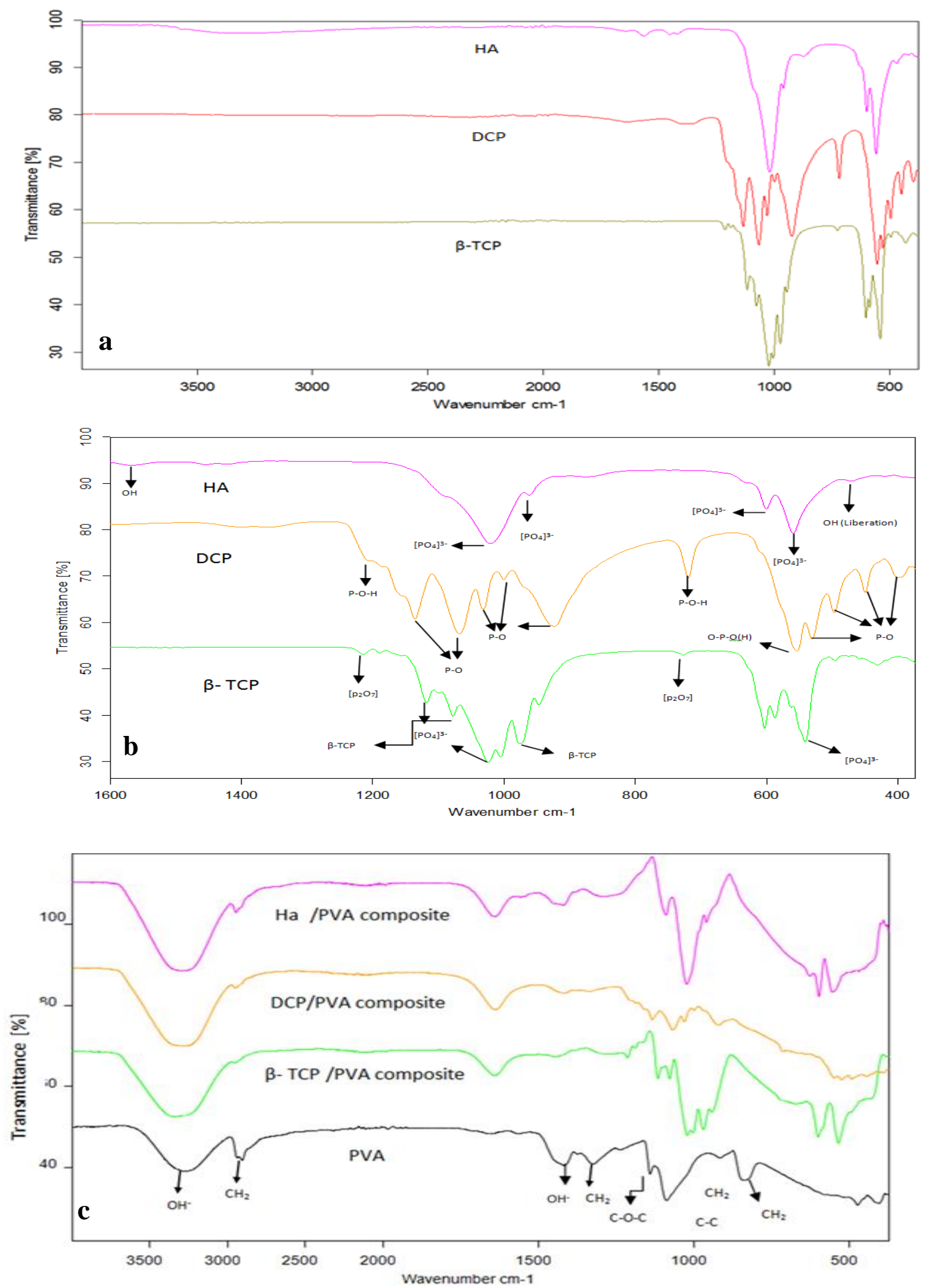

Figure 4. a, b -FTIR spectra for HA, DCP and TCP powders. c- FTIR spectra for HA/PVA, DCP/PVA, $\beta$-TCP/PVA composites and PVA 
Accepted by Journal of Biomaterials and Tissue Engineering, 31 July 2015

Table 1. Assignment of FTIR Absorption Bands of Pure Powders and Composites

\begin{tabular}{|c|c|c|c|c|c|c|c|}
\hline \multicolumn{4}{|c|}{ Peaks for Powder $\left(\mathrm{cm}^{-1}\right)$} & \multicolumn{3}{|c|}{ Peaks for composites $\left(\mathrm{cm}^{-1}\right)$} & \multirow[t]{2}{*}{ Assignment } \\
\hline HA & DCP & TCP & PVA & HA/PVA & DCP/PVA & $\beta \mathrm{TCP} / \mathrm{PVA}$ & \\
\hline \multirow[t]{5}{*}{3361} & & & & & & & Stretching and bending mode of $\mathrm{H}_{2} \mathrm{O}$ (Water) \\
\hline & & & 3266 & 3283 & 3284 & 3287 & Stretching of $\mathrm{OH}$ \\
\hline & & & & 2937 & & & Asymmetric stretching of $\mathrm{CH}_{2}$ \\
\hline & & & 2907 & 2909 & 2912 & & Asymmetric stretching of $\mathrm{CH}_{2}$ \\
\hline & & & & & 2323 & 2069 & $\mathrm{P}-\mathrm{O}$ \\
\hline 1646 & 1639 & & & 1656 & 1647 & & $\mathrm{O}=\mathrm{H}, \mathrm{C}=\mathrm{C}$ \\
\hline 1568 & & & & 1565 & & & $\mathrm{O}=\mathrm{H}, \mathrm{C}=\mathrm{C}$ \\
\hline 1455 & 1400 & & & 1428 & & & Impurities $\left(\mathrm{CO}_{2}^{3-}\right)$ \\
\hline \multirow[t]{8}{*}{1420} & & & & & & & Impurities $\left(\mathrm{CO}_{2}^{3-}\right)$ \\
\hline & & & & 14171418 & & 1427 & O-H,C-H bending, $\gamma\left(\mathrm{CH}_{2}\right), \delta(\mathrm{OH})$ \\
\hline & & & & 1325 & 1344 & & $\delta(\mathrm{OH})$ with $\mathrm{CH}$ wagging \\
\hline & & & & 1237 & & & $\mathrm{C}-\mathrm{O}-\mathrm{C}$ \\
\hline & & 1214 & & & & 1215 & Symmetric stretching of $\mathrm{PO}_{4}{ }^{3-}$ \\
\hline & & & & 1138 & & & Stretching of CO (crystalline sequence of PVA) \\
\hline & 1136 & 1118 & & & 1126 & 1117 & Symmetric stretching of $\mathrm{PO}_{4}^{3-}$ \\
\hline & & & & 1088 & & & Stretching of $\mathrm{CC}$ and bending of $\mathrm{OH}$ (amorphous sequence of PVA) \\
\hline \multirow[t]{3}{*}{1021} & 1068 & 1007 & & 1086 & 1060 & & Symmetric stretching of $\mathrm{PO}_{4}{ }^{3-}$ \\
\hline & 1032 & 1024 & & 1024 & & 1024 & Symmetric stretching of $\mathrm{PO}_{4}^{3-}$ \\
\hline & 1000 & 1005 & & & & & Symmetric stretching of $\mathrm{PO}_{4}^{3-}$ \\
\hline 962 & & 977,947 & & 981,962 & 992,889 & 972 & stretching of $\mathrm{HPO}_{4}^{2-}$ \\
\hline \multirow[t]{4}{*}{875} & 924 & & & & & & Stretching of $\mathrm{P}-\mathrm{O}-\mathrm{H}$ \\
\hline & & & & 917 & & & Bending of $\mathrm{CH}_{2}$ \\
\hline & & & & 841,840 & & & Rocking of $\mathrm{CH}_{2}$ \\
\hline & 719 & 727 & & & & 728 & Stretching of $\mathrm{P}_{2} \mathrm{O}$ \\
\hline
\end{tabular}



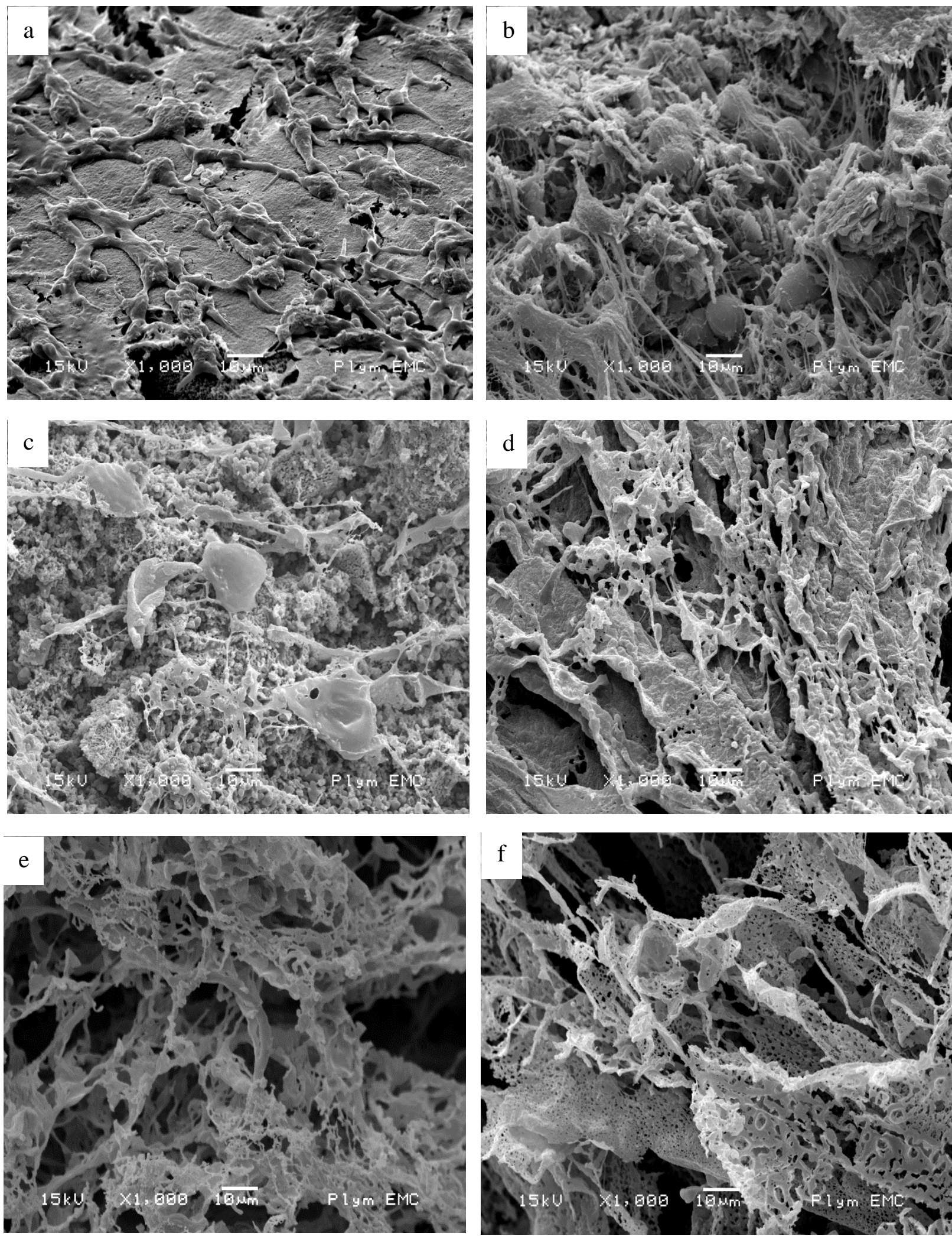

Figure 5. SEM analysis of biocompatibility test. a,b,c -24 h cell test result of HA,DCP and $\beta$ TCP respectively. d,e,f- seven day cell test results of HA, DCP and $\beta$-TCP respectively. 
Accepted by Journal of Biomaterials and Tissue Engineering, 31 July 2015
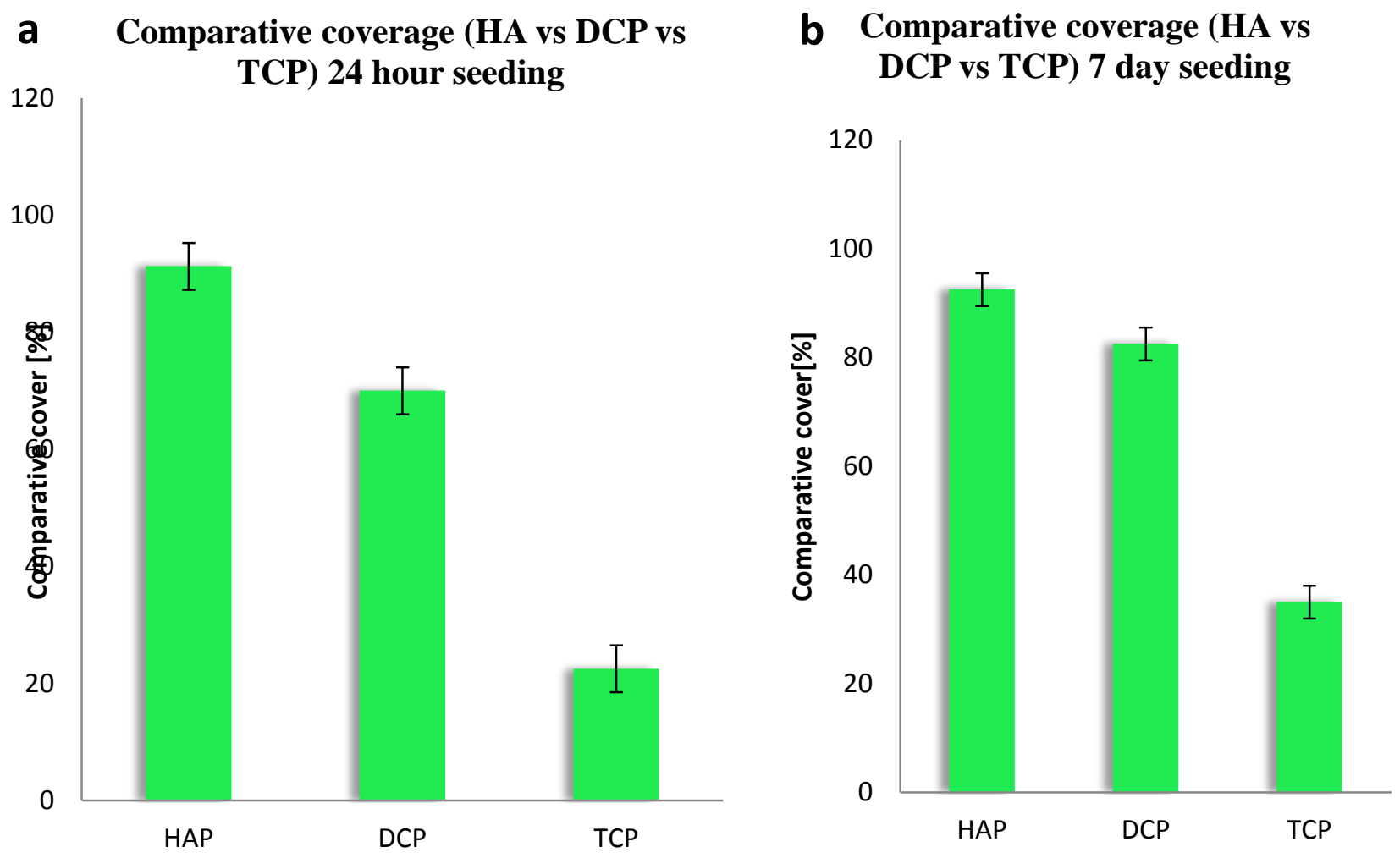

Figure 6.Quantitative analysis of biocompatibility. a - Coverage of samples by cells after 24 h. $\mathbf{b}$ - Coverage of samples by cells after seven days. 


\section{REFERENCES}

1. W.R.Moore, S.E.Graves, G.I.Bain, Synthetic bone graft substitutes. ANZ journal of surgery,71(6):354-61,(2001).

2. J-H.Kühne, R. Bartl, B. Frisch, et al., Bone formation in coralline hydroxyapatite: Effects of pore size studied in rabbits. Acta Orthopaedica;65(3):246-52,(1994).

3. R.A.Yukna. Synthetic bone grafts in periodontics. Periodontology19931(1):9299,(2000).

4. P.V.Giannoudis, H.Dinopoulos, E.Tsiridis, Bone substitutes: an up date. Injury, 36 Suppl 3:S20-7,(2005).

5. M.Vandrovcova, L.Bacakova, Adhesion, growth and differentiation of osteoblasts on surface-modified materials developed for bone implants. Physiol Res;60(3):403-17, (2011).

6. T.W.Bauer, G.F.Muschler, Bone graft materials: an overview of the basic science. Clinical orthopaedics and related research 371:10-27,(2000).

7. R.Z.LeGeros, Calcium phosphate-based osteoinductive materials. Chemical reviews,108(11):4742-53(2008).

8. K.Miyazaki TH, J.M. Antonucci,S.Takagi,L.C.Chow. Polymeric Caclium Phosphate cements: analysis of reaction products and properties Dental materials, 9(1):41-45 (1993).

9. S.Nandi, S.Roy, P.Mukherjee, et al. Orthopaedic applications of bone graft \& graft substitutes: a review, (2010).

10. B.Liu, D-x.Lun. Current Application of $\beta$-tricalcium Phosphate Composites in Orthopaedics. Orthopaedic Surgery, 4(3):139-44(2012).

11. M. Vallet-Regí, J.M.González-Calbet, Calcium phosphates as substitution of bone tissues. Progress in Solid State Chemistry 32(1-2):1-31,(2004).

12. G.Daculsi, Biphasic calcium phosphate concept applied to artificial bone, implant coating and injectable bone substitute. Biomaterials,19(16):1473-78,(1998).

13. P.D. Costantino, C.D. Friedman, K. Jones, et al., Hydroxyapatite cement: I. basic chemistry and histologic properties. Archives of Otolaryngology-Head \& Neck Surgery,117(4):379-84 (1991).

14. K. Ishikawa, S. Takagi, L.C. Chow, K. Suzuki, Reaction of calcium phosphate cements with different amounts of tetracalcium phosphate and dicalcium phosphate anhydrous. J Biomed Mater Res, 46(4):504-10 (1999).

15. W.E. Brown, L.C. Chow, Dental resptorative cement pastes: Google Patents, (1985).

16. W.E. Brown, L.C.Chow, Dental restorative cement pastes: Google Patents, (1990).

17. S.Yamada, D.Heymann, J.M.Bouler, G.Daculsi, Osteoclastic resorption of calcium phosphate ceramics with different hydroxyapatite/ $\beta$-tricalcium phosphate ratios. Biomaterials,18(15):1037-41, (1997).

18. M. Kamitakahara, C. Ohtsuki, T.Miyazaki, Review Paper: Behavior of Ceramic Biomaterials Derived from Tricalcium Phosphate in Physiological Condition. Journal of Biomaterials Applications, 23(3):197-212, (2008).

19. D-M. Liu, Q. Yang, T. Troczynski, W.J.Tseng, Structural evolution of sol-gel-derived hydroxyapatite. Biomaterials, 23(7):1679-87, (2002).

20. M. Stoia, M. Ionescu, O. Stefănescu, R. Murgan, M.Stefanescu, Preparation of $\beta$ Tricalcium Phosphate from Precursors Obtained by a Wet Precipitation Method. 
21. I.Manjubala, T.P Sastry, R.V.S. Kumar, Bone In-growth Induced by Biphasic Calcium Phosphate Ceramic in Femoral Defect of Dogs. Journal of Biomaterials Applications,19(4):341-60 (2005).

22. J.M. Bouler, R.Z. LeGeros, G.Daculsi, Biphasic calcium phosphates: Influence of three synthesis parameters on the HA/ $\beta-$ TCP ratio. Journal of biomedical materials research, 1(4):680-84 (2005).

23. L. Nie, D. Chen, J. Suo, et al., Physicochemical characterization and biocompatibility in vitro of biphasic calcium phosphate/polyvinyl alcohol scaffolds prepared by freezedrying method for bone tissue engineering applications. Colloids and Surfaces B: Biointerfaces, 100(0):169-76, (2012).

24. H.S. Costa, A.A.P. Mansur, M.M. Pereira, H.S. Mansur, Engineered hybrid scaffolds of poly(vinyl alcohol)/bioactive glass for potential bone engineering applications: synthesis, characterization, cytocompatibility, and degradation. J. Nanomaterials,4$4(2012)$.

25. K.Y. Lee, D.J.Mooney, Hydrogels for tissue engineering. Chemical reviews, 101(7):1869-80 (2001).

26. C.R. Nuttelman, S.M. Henry, K.S.Anseth, Synthesis and characterization of photocrosslinkable, degradable poly(vinyl alcohol)-based tissue engineering scaffolds. Biomaterials, 23(17):3617-26, (2002).

27. B.L. Seal, T.C. Otero, A. Panitch, Polymeric biomaterials for tissue and organ regeneration. Materials Science and Engineering: R: Reports, 34(4-5):147-230 (2001).

28. J. Bonilla, E. Fortunati, L. Atarés, A. Chiralt, J.M. Kenny, Physical, structural and antimicrobial properties of poly vinyl alcohol-chitosan biodegradable films. Food Hydrocolloids, 35(0):463-70, (2014).

29. H. R. Le, K. Natesan, S.Pranti-Haran, Mechanical property and biocompatibility of coprecipitated nano hydroxyapatite-gelatine composites. Journal of Advanced Ceramics, 4 ( 2015), in press.

30. L. Galea, M. Bohner, J. Thuering, et al., Control of the size, shape and composition of highly uniform, non-agglomerated, sub-micrometer $\beta$-tricalcium phosphate and dicalcium phosphate platelets. Biomaterials, 34(27):6388-401, (2013). 